\title{
Effects of Inhibiting Glycoprotein MUC5AC by Seaweed Ecklonia cava Extract in human Airway Epithelial Cells
}

\author{
Sung-Gyu Lee ${ }^{1, ; ; * *}$ and Sang-Oh Kwon ${ }^{1, * *}$ \\ ${ }^{l}$ Department of Medical Laboratory Science, College of Health Science, \\ Dankook University, Cheonan-si, Chungnam 31116, Korea \\ ${ }^{2} R \& D$ Center, S\&D Co., Ltd., Cheongju-si, Chungcheongbuk-do 28156, Korea
}

In the present study, antioxidant and MUC5AC mucin inhibition activities were measured in Ecklonia cava (E. cava) extract. The E. cava extract showed the total polyphenol and flavonoid contents of $607.40 \pm 19.44 \mu \mathrm{g} \mathrm{GAE} / \mathrm{mg}$ and $13.33 \pm 5.28 \mu \mathrm{g} \mathrm{QE} / \mathrm{mg}$, respectively. The free radical scavenging activity of $E$. cava extract was high in the DPPH radical scavenging activity $\left(\mathrm{RC}_{50} 7.08 \mu \mathrm{g} / \mathrm{mL}\right)$ and $\mathrm{ABTS}+$ radical scavenging activity $\left(\mathrm{RC}_{50} 4.74 \mu \mathrm{g} / \mathrm{mL}\right)$. Also, we investigated whether E. cava extract affects airway MUC5AC mucin gene expression, production and secretion induced by phorbol 12-myristate 13-acetate (PMA) from NCI-H292 cells. Cells were treated with E. cava extract and then stimulated with PMA for $24 \mathrm{~h}$. The E. cava extract inhibited the gene expression of MUC5AC mucin from NCI-H292 cells. This result suggests that $E$. cava extract can inhibit the gene expression of mucin induced by PMA through directly acting on airway epithelial cells.

Key Words: Ecklonia cava, MUC5AC, NCI-H292, PMA, Seaweed

호흡기에 존재하는 점액(mucus)은 다양한 병원성 미생 물, 환경성 유해입자, 화학물질에 대한 인체의 방어작용 기능에서 매우 중요하다. 이러한 기도 점액의 작용은 점 액의 주 구성요소인 뮤신(mucin)의 점탄성에 기인된다 (Mutschler and Derendorf, 1995). 뮤신은 고분자의 점액성 당단백질로, 기도의 술잔세포(goblet cell)에서 주로 생성된 다(Lillehoj et al., 2013). 그러나 기도 점액의 과다분비는 천 식, 만성 기관지염, 낭포성 섬유증 및 기관지 확장증을 비 롯한 중증 폐질환과 관련된 주요 증상 중 하나이다(Ellis, 1985). 따라서 점액의 점성을 부여하는 뮤신의 생성을 조 절하는 약물을 찾는 것은 기도질환의 치료에 중요한 방 향이 될 수 있다.

한편 항산화 물질은 인체 내 대사 과정 중에 산소의
불완전한 환원으로 발생되는 superoxide ion $(\mathrm{O} 2)$, hydroxyl radical $\left(\mathrm{OH}^{-}\right)$, hydrogen peroxide $\left(\mathrm{H}_{2} \mathrm{O}_{2}\right)$ 와 같은 활성산소종 에 의한 산화반응을 저해하여 활성산소에 의한 다양한 질환들을 예방해주는 생리활성 물질이다. 체내에서 활성 산소종이 증가되면 폐 손상 등 인체에서 독성을 일으킬 수 있다는 보고(Freeman and Crapo, 1982; Freeman et al., 1982)가 있으며 증가된 산화물들은 염증유발, 면역저하, 뮤신 과분비 등의 형태로 폐질환 발생에 관여한다는 보 고가 있다(Lee, 1997)

해양식물 중 특히 해조류는 식품, 기능성식품, 동물용 사료, 화장품, 의약품 등에 널리 활용되고 있다(Dhargalkar and Verlecar, 2009). 해양식물, 특히 해조류는 널리 해조 류 중 감태는 한국의 제주도 바다에서 주로 서식하고

Received: November 9, 2021 / Revised: December 10, 2021 / Accepted: December 10, 2021

*Professor, ${ }^{* *}$ Chief Technology Officer

${ }^{\dagger}$ Corresponding author: Sung-Gyu Lee. Department of Medical Laboratory Science, College of Health Science, Dankook University, Cheonan-si, Chungnam 31116 , Korea.

Tel: +82-41-550-1465, Fax: +82-41-559-7934, e-mail: sung-gyu@dankook.ac.kr

(C) The Korean Society for Biomedical Laboratory Sciences. All rights reserved.

(a) This is an Open Access article distributed under the terms of the Creative Commons Attribution Non-Commercial License (http://creativecommons.org/licenses/by-nc/3.0/) which permits unrestricted non-commercial use, distribution, and reproduction in any medium, provided the original work is properly cited. 
있으며 갈조식물 다시마목 미역과에 속하는 다년생 해 조류로 학명은 Ecklonia cava (E. cava)이다. 감태의 성분 으로는 eckol, dieckol, phlorofucofuroeckol A, triphlorethol-A, phloroglucinol, dioxinodehydroeckol, fucodiphlorethol G와 같 이 폴리페놀 성분인 플로로탄닌 계열 성분을 다량 함유 하고 있다(Ahn et al., 2004; Kang et al., 2005; Kang et al., 2007; Kong et al., 2009). 이처럼 감태는 다량의 해양 유래 폴리페놀 성분을 함유하고 있어 항산화, 항암, 항응고제, 수면장애 개선 등 다양한 생리활성 효과에 대한 연구들이 보고되고 있다(Heo et al., 2005; Heo et al., 2005; Athukorala et al., 2006; Kim et al., 2006). 하지만, 감태가 호흡기질환에서 발생하는 점액 과분비에 미치는 영향에 대해서는 연구가 미미한 실정이다.

따라서, 본 연구에서는 감태 추출물의 항산화 효과와 인간 기도 상피세포인 NCI-H292 세포에서 PMA에 의해 증가된 뮤신의 유전자 발현에 어떠한 영향을 나타내는지 를 검증함으로써, 효과적인 기도 점액 과다생성 조절 소 재의 개발을 위한 기초자료를 제공하고자 하였다.

항산화 활성에 사용된 시약은 Folin 시약, $\mathrm{Na}_{2} \mathrm{CO}_{3}$, gallic acid, aluminium nitrate, potassium acetate, quercetin, ascorbic acid, 1,1-diphenyl-2-picryl hydrazyl (DPPH), 2,2'-Azino-bis (3-ethylbenzothiazoline-6-sulfonic acid) diammonium salt (ABTS), potassium persulfate는 Sigma-Aldrich Chemical Co. (St. Louis, MO, USA)로부터 구입하여 사용하였다. 세포 배양에 사용된 시약은 RPMI1640, antibiotic, fetal bovine serum (FBS), trypsin-EDTA는 Gibco BRL Co. (Grand Island, $\mathrm{NY}, \mathrm{USA})$ 로부터 구입하였다. 세포독성에 사용된 3-(4,5dimethyl-thiazol-2-yl)-2,5-diphenyltetrazoliumbromide (MTT) 는 Amresco (Amresco, Solon Ind. Ohio, USA)사로부터 구입 하였고, PCR 시험에 사용된 primer는 Bioneer (Bioneer, USA)사에서 합성하였으며, trizol solution은 Molecular Research Center (Molecular Research Center, USA), 1-bromo30-chloropropane은 Sigma-Aldrich Chemical Co.에서 구입하 여 사용하였다.

감태 추출물은 (주)에스앤디(Osong, Korea)에서 제조한 감태 에탄올 추출물(Lot. No. 210222-001)을 제공받아 실험 에 사용하였다.

감태 추출물의 총 폴리페놀 함량을 구하기 위해 FolinDenis 법(Folin and Denis, 1912)을 응용하여 측정하였다. 감 태 추출물과 표준물질인 gallic acid를 농도 별로 증류수로 희석하여 $50 \%$ folin 시약을 96 well에 동량 혼합하여 3 분 간 반응시킨 후, $10 \%$ sodium carbonate를 동량 혼합하여
1시간 동안 실온에서 방치하였다. 그 후, Microplate Spectrophotometer (xMARK, BIO-RAD Co., California, USA)를 사용하여 $700 \mathrm{~nm}$ 의 파장에서 흡광도를 측정하여 gallic acid로부터 얻어진 표준곡선으로 감국 추출물의 총 폴리 페놀 함량을 구하였다.

감태 추출물의 총 플라보노이드 함량은 Nieva Moreno 등 (2000)의 방법을 응용하여 측정하였다. 농도별 감태 추출물 $100 \mu \mathrm{L}$ 와 $80 \%$ 에탄올 $860 \mu \mathrm{L}$ 을 혼합하고, $10 \%$ aluminium nitrate $20 \mu \mathrm{L}$ 와 $1 \mathrm{M}$ potassium acetate $20 \mu \mathrm{L}$ 을 첨 가하여 실온에서 40 분 동안 반응시킨 뒤, $415 \mathrm{~nm}$ 파장에 서 흡광도를 측정하였다. 이때 quercetin을 표준물질로 이 용하여 총 플라보노이드 함량을 구하였다.

자유 라디칼 소거 활성은 stable한 라디칼인 $\mathrm{DPPH}$ 와 $\mathrm{ABTS}$ 라디칼에 대한 환원력을 측정하였다. 먼저 $\mathrm{DPPH}$ 라디칼 소거 활성은 $99 \%$ 메탄올에 감태 추출물을 농도 별로 희석하여 $517 \mathrm{~nm}$ 파장에서 초기값을 측정한 후, 메 탄올에 용해된 $0.15 \mathrm{mM} \mathrm{DPPH}$ 용액을 첨가하여 실온에서 30 분 동안 반응시킨 후 $517 \mathrm{~nm}$ 파장에서 흡광도를 측정 하였다. ABTS 라디칼을 이용한 항산화력 측정은 $\mathrm{Re}$ 등 (1999)의 방법을 응용하였다. 최종 반응 농도가 $7 \mathrm{mM}$ $\mathrm{ABTS}$ 와 $2.45 \mathrm{mM}$ potassium persulfate가 되도록 동량 혼 합하여 암실에서 24시간 동안 반응시켜 $\mathrm{ABTS}^{+}$을 형성시 킨 후 $732 \mathrm{~nm}$ 파장에서 흡광도 값이 $0.70( \pm 0.02)$ 이 되도 록 phosphate buffered saline (PBS, pH 7.4)로 조절하였다. 농도 별 감태 추출물 $20 \mu \mathrm{L}$ 에 $\mathrm{ABTS}^{+\cdot}$ 용액 $180 \mu \mathrm{L}$ 를 혼 합하여 1 분 동안 반응시킨 후 흡광도를 측정하였다. 각 시료의 라디칼 소거 활성은 시료를 첨가하지 않은 대조 구의 흡광도를 절반으로 환원시키는데 필요한 시료의 농 도인 $\mathrm{RC}_{50}$ 을 산출하여 양성대조군인 ascorbic acid와 비교 분석 하였다.

본 연구에서 사용된 사람 호흡기 상피세포주(human airway epithelial cell line)인 NCI-H292 세포는 한국세포주 은행에서 구입하여 사용하였다. 세포의 배양은 $10 \% \mathrm{FBS}$ 와 $1 \%$ penicillin-streptomycin으로 구성된 RPMI 1640 배지 를 사용하였고 $37^{\circ} \mathrm{C}, 5 \% \mathrm{CO}_{2}$ 조건이 유지되는 세포배양 기에서 배양하였으며, 2 3일 주기로 계대 배양하여 실험 을 진행하였다.

NCI-H292 세포를 96 well plate에 $1 \times 10^{4}$ cells/well로 분 주하여 24시간 동안 배양하였다. 이후 무혈청 배지로 교 환 후 감태 추출물 $(10,50,100 \mu \mathrm{g} / \mathrm{mL})$ 단독 혹은 $100 \mathrm{nM}$ $\mathrm{PMA}$ 와 복합으로 처리하여 다시 24시간 동안 배양하였다. 그 후 $5 \mathrm{mg} / \mathrm{mL}$ MTT 시약을 $10 \mu \mathrm{L}$ 씩 첨가한 후 4시간 동 
Table 1. The sequences of primers used in this study

\begin{tabular}{|c|c|c|c|}
\hline Gene & Product size (bp) & & Sequences \\
\hline \multirow{2}{*}{ MUC5AC } & \multirow{2}{*}{458} & Forward & 5'-TGA TCA TCC AGC AGG GCT-3' \\
\hline & & Reverse & 5'-CCG AGC TCA GAGGAC ATA TGG G-3' \\
\hline \multirow{2}{*}{ Rig/S15 } & \multirow{2}{*}{361} & Forward & 5'-TTC CGC AAG TTC ACC TAC C-3' \\
\hline & & Reverse & 5'-CGG GCC GGC CAT GCT TTA CG-3' \\
\hline
\end{tabular}

안 배양하여 MTT가 환원되도록 하였다. 그 후 상등액을 제거하고 $\mathrm{DMSO}$ 를 $100 \mu \mathrm{L}$ 씩 분주하여 formazone된 cell 결정을 용해시킨 후 Microplate Spectrophotometer (xMARK, $\mathrm{BIO}-\mathrm{RAD} \mathrm{Co}$.)를 사용하여 $550 \mathrm{~nm}$ 에서 흡광도를 측정하 였다. 세포생존율은 대조군에 대한 세포생존율을 백분율 로 표시하였다.

RNA 분리 및 reverse transcription-polymerase chain reaction (RT-PCR)을 수행하기 위해 6 well plate에 $10 \%$ FBS 가 첨가된 배지를 이용하여 세포를 $5 \times 10^{5}$ cells/well의 농 도로 24 시간 부착시킨 후 무혈청 배지로 갈아준 다음 감 태 추출물 $(10,20,40 \mu \mathrm{g} / \mathrm{mL})$ 을 전처리 하고 30 분 후에 $100 \mathrm{nM}$ phorbol 12-myristate 13-acetate (PMA)를 처리하였 다. 24시간 후 세포를 회수하여 trizol reagent (Molecular Research center, Inc.)를 사용하여 RNA를 분리하였다. 분 리된 RNA는 NanoDrop (Thermo Scientific, Waltham, USA) 을 이용하여 정량하였다. 분리된 RNA $1 \mu \mathrm{g}$ 과 oligo DT $(100 \mathrm{pM}) 1 \mu \mathrm{L}$ 를 포함하여 총량이 $12 \mu \mathrm{L}$ 되도록 $\mathrm{DEPC}$ 를 첨가한 다음 $70^{\circ} \mathrm{C}$ 에서 10 분간 반응시켰다. 그리고 $\mathrm{RT}$ premix kit (Bioneer)의 사용자 설명서에 따라 역전사 반응 을 진행시켰다. MUC5AC와 Rig/S15 유전자에 대한 PCR 은, 각각의 역전사 반응에서 얻은 $\mathrm{cDNA}$ 산물 $2 \mu \mathrm{L}$ 를 PCR premix kit (Bioneer)의 사용자 설명서에 따라 진행시 켰다. MUC5AC와 Rig/S15의 primer sequence는 Table 1과 같으며 증폭반응을 위하여, $\mathrm{PCR}$ 을 40회 실시(PCR thermal cycler, Takara MP-300, Japan) 하였으며, denaturation은 $94^{\circ} \mathrm{C}$ 에서 $30 \mathrm{~s}$, annealing은 $60^{\circ} \mathrm{C}$ 에서 $30 \mathrm{~s}$, extension은 $72^{\circ} \mathrm{C}$ 에서 $45 \mathrm{~s}$ 간 각각 시행하였다. RNA의 역전사 반응 및 중합효소 연쇄반응으로 증폭된 cDNA 산물들을 ethidium bromide 가 첨가된 $1.2 \%$ agarose gel로 전기영동을 실시하여 분석 하였다.

실험 결과는 SPSS statistics (ver. 25, IBM Co., Armonk, $\mathrm{NY}, \mathrm{USA}$ )을 이용하여 mean \pm standard error of mean으로 나타내었으며, ANOVA를 실시하였고 평균값의 통계적 유 의성은 $P<0.05$ 수준에서 Duncan's multiple range test를 이
Table 2. Contents of total polyphenols and flavonoids of $E$. cava extract

\begin{tabular}{lcc}
\hline \hline Sample & $\begin{array}{c}\text { Total polyphenols } \\
\left(\mu \mathrm{g} \mathrm{GAE}^{1)} / \mathrm{mg}\right)\end{array}$ & $\begin{array}{c}\text { Total flavonoids } \\
\left(\mu \mathrm{g} \mathrm{QE}^{2)} / \mathrm{mg}\right)\end{array}$ \\
\hline E. cava extract & $607.40 \pm 19.44^{3)}$ & $13.33 \pm 5.28$ \\
\hline${ }^{1)}$ Total phenolic content was expressed as $\mu \mathrm{g} / \mathrm{mg}$ gallic acid equi- \\
valent \\
2) $\begin{array}{l}\text { Total flavonoid content was expressed as } \mu \mathrm{g} / \mathrm{mg} \text { quercetin equi- } \\
\text { valent }\end{array}$ \\
${ }^{3)}$ Each value is mean \pm S.D. $(\mathrm{n}=3)$
\end{tabular}

용하여 분석하였다.

폴리페놀류는 식물에 다량으로 분포되어 있는 이차 대 사산물 중 하나로 flavonoid, lignan, phenolic acid, stillbene 등의 4종으로 구분되는데 이 성분들은 식물의 이차 대사 산물로서 생체 내 강한 항산화 작용을 하는 것으로 잘 알려져 있다(Cragg et al., 1997). 감태 추출물의 총 폴리페 놀 함량 및 플라보노이드 함량을 측정한 결과 Table 2 와 같이 각각 $607.40 \pm 19.44 \mu \mathrm{g} \mathrm{GAE} / \mathrm{mg}, 13.33 \pm 5.28 \mu \mathrm{g} \mathrm{QE} / \mathrm{mg}$ 의 함량을 보였다. 감태는 폴리페놀 화합물 중 생리활성 물질로 잘 알려진 eckol류가 다른 해조류에 비해 다량 함 유되어 있어 항산화 활성이 우수한 것으로 알려져 있다. $\mathrm{Kim}$ 등 (Kim et al., 2015)의 연구에서 감태의 폴리페놀 함 량이 $144.69 \pm 0.43 \mathrm{mg} / \mathrm{g}$ 으로 나타난 것에 비해 본 연구에 서 사용된 감태 추출물의 경우 약 4 배 이상 높은 함량을 보였다. 이는 감태 산지 및 추출방법에 따라 함량의 차이 가 있는 것으로 사료되며 우수한 항산화 성분을 이용한 기능성 소재로의 개발 가능성이 기대된다.

감태 추출물의 항산화 활성은 $\mathrm{DPPH}$ 및 $\mathrm{ABTS}$ 라디칼 을 이용하여 확인하였다. 각 농도 별 $\mathrm{DPPH}$ 및 $\mathrm{ABTS}$ 라 디칼 소거 활성을 백분율로 나타낸 결과를 Table 3 에 나 타내었다. DPPH 라디칼은 비교적 안정한 라디칼로, 항산 화 물질을 첨가하여 diphenylpicryl hydrazine으로 환원되는 원리를 이용하여 항산화능의 정도를 측정할 수 있다(Lee and Cho, 2016). 감태 추출물의 DPPH 라디칼 소거 활성은 
Table 3. DPPH and ABTS radical scavenging activities of the extracts of E. cava extract

\begin{tabular}{|c|c|c|c|c|c|}
\hline \multicolumn{2}{|c|}{ Sample } & \multicolumn{2}{|c|}{ DPPH radical } & \multicolumn{2}{|c|}{ ABTS radical } \\
\hline Sample name & $\begin{array}{c}\text { Concentration } \\
(\mu \mathrm{g} / \mathrm{mL})\end{array}$ & $\begin{array}{c}\text { Scavenging activity } \\
(\%)\end{array}$ & $\begin{array}{c}\mathrm{RC}_{50}^{11)} \\
(\mu \mathrm{g} / \mathrm{mL})\end{array}$ & $\begin{array}{c}\text { Scavenging activity } \\
(\%)\end{array}$ & $\begin{array}{c}\mathrm{RC}_{50} \\
(\mu \mathrm{g} / \mathrm{mL})\end{array}$ \\
\hline \multirow{4}{*}{ E. cava extract } & 1 & $11.27 \pm 1.50^{\mathrm{g} 2) 3)}$ & \multirow{4}{*}{$7.08 \pm 0.18^{\mathrm{a}}$} & $13.31 \pm 1.82^{\mathrm{d}}$ & \multirow{4}{*}{$4.74 \pm 0.11$} \\
\hline & 2.5 & $17.63 \pm 0.51^{\mathrm{f}}$ & & $29.65 \pm 1.80^{\mathrm{c}}$ & \\
\hline & 5 & $38.37 \pm 2.31^{\mathrm{e}}$ & & $58.29 \pm 1.53^{\mathrm{b}}$ & \\
\hline & 10 & $69.30 \pm 0.42^{\mathrm{d}}$ & & $91.80 \pm 1.09^{\mathrm{a}}$ & \\
\hline \multirow{4}{*}{ Ascorbic acid } & 1 & $42.21 \pm 5.49^{\mathrm{e}}$ & \multirow{4}{*}{$1.34 \pm 0.11^{\mathrm{b}}$} & $10.61 \pm 0.85^{\mathrm{d}}$ & \multirow{4}{*}{$4.68 \pm 0.08$} \\
\hline & 2.5 & $90.89 \pm 1.10^{\mathrm{c}}$ & & $29.12 \pm 0.36^{\mathrm{c}}$ & \\
\hline & 5 & $95.32 \pm 0.02^{\mathrm{b}}$ & & $56.65 \pm 0.62^{\mathrm{b}}$ & \\
\hline & 10 & $99.21 \pm 1.14^{\mathrm{a}}$ & & $93.44 \pm 0.07^{\mathrm{a}}$ & \\
\hline
\end{tabular}

1) Amount required for $50 \%$ reduction of scavenging activity

2) Data are mean \pm standard deviation $(n=3)$

3) Different superscripts in a column indicate significant differences at $P<0.05$ by Duncan's multiple range test

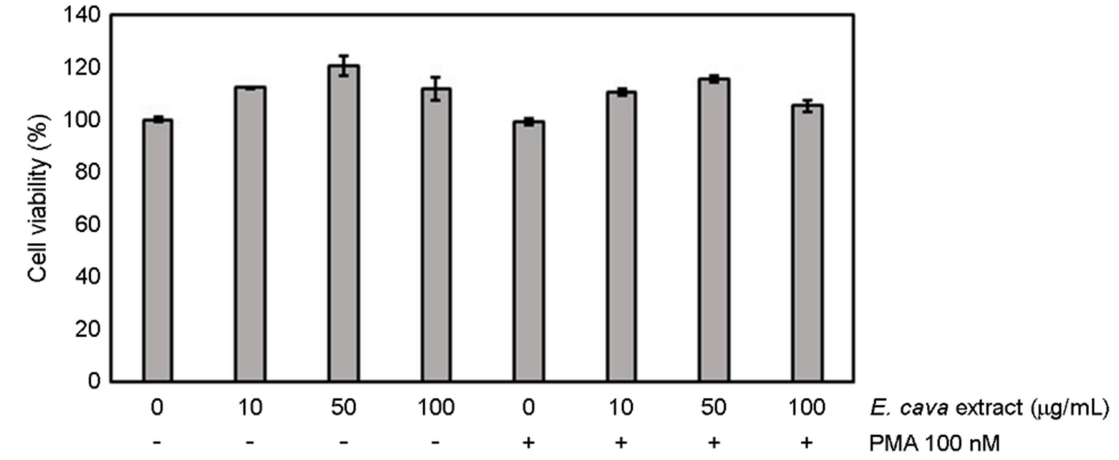

Fig. 1. Effects of $E$. cava extract or $E$. cava extract with PMA on cell viability in NCI-H292 cells. NCI-H292 cells were treated with $E$. cava extract $(0,10,50$, and $100 \mu \mathrm{g} / \mathrm{mL}$ ) or $E$. cava extract with PMA $100 \mathrm{nM}$ for $24 \mathrm{~h}$.
천연 항산화제인 ascorbic acid와 $\mathrm{RC}_{50}$ 으로 비교하였다. 실 험 결과, 감태 추출물의 $\mathrm{RC}_{50}$ 은 $7.08 \mu \mathrm{g} / \mathrm{mL}$ 로 대조군인 ascorbic acid $\left(\mathrm{RC}_{50}=1.34 \mu \mathrm{g} / \mathrm{mL}\right)$ 와 비교하였을 때, 라디칼 소거 활성이 약 5 배 정도 낮은 것으로 나타났다. $\mathrm{ABTS}$ 를 이용한 항산화능의 측정은 $\mathrm{ABTS}$ 와 potassium persulfate 반응으로 청록색이 $\mathrm{ABTS}^{+}$라디칼을 생성하는 방법으로 항산화 물질을 첨가하면 탈색된 색의 흡광도를 측정하여 항산화능을 측정하는 방법이다. 감태 추출물의 $\mathrm{ABTS}$ 라 디칼 소거 활성은 $1,2.5,5,10 \mu \mathrm{g} / \mathrm{mL}$ 의 농도 별로 각각 $13.31 \%, 29.65 \%, 58.29 \%, 91.80 \%$ 로 낮은 농도에서 높은 $\mathrm{ABTS}$ 라디칼 소거 활성을 보였고, 대조군으로 사용된 ascorbic acid와 $\mathrm{RC}_{50}$ 을 비교하였을 때 각각 $4.74,4.68 \mu \mathrm{g} /$ $\mathrm{mL}$ 로 유사한 항산화능을 보였다. Yoo 등 (2015)의 연구에 서 감태 $50 \%$ 에탄올 추출물의 자유 라디칼 소거 활성 $\mathrm{RC}_{50}$ 이 $22.15 \mu \mathrm{g} / \mathrm{mL}$ 로 본 연구에 사용된 추출물이 약 4.7 배 정도 높은 항산화 활성을 보였다. 이는 본 연구에서

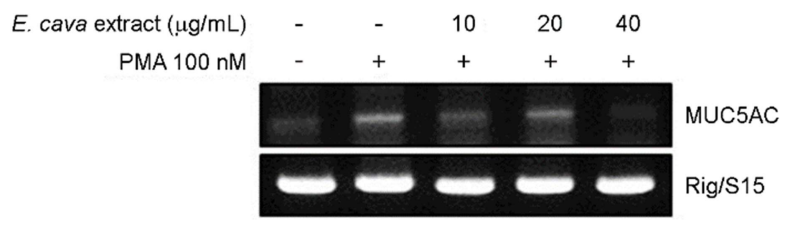

Fig. 2. Effects of $E$. cava extract on PMA-induced MUC5AC gene expression in NCI-H292 cells. Total RNA was isolated and MUC5AC mRNA levels were analyzed by RT-PCR. The PCR products were separated on $1.2 \%$ agarose gel and stained with ethidium bromide.

사용된 감태 추출물에서 항산화 활성이 큰 성분들이 많 이 추출되어 있음을 시사한다.

MTT법을 이용한 세포독성 검사에서 감태 추출물을 다 양한 농도 $(10,50,100 \mu \mathrm{g} / \mathrm{mL})$ 로 24시간 동안 처리하였을 때, 세포독성 및 증식에 영향을 나타내지 않았으며, protein kinase $\mathrm{C}(\mathrm{PKC})$ 의 활성화제인 PMA 처리 시에도 세포독성 
은 관찰되지 않았다(Fig. 1).

호흡기에 존재하는 뮤신은 현재까지 20 여종의 MUC 유전자가 보고되고 있다. 그 중 MUC5AC 뮤신이 인간 의 호흡기에서 발견되는 젤형성 뮤신을 구성하고 있다 (Rogers and Barnes, 2006). 인체 기도에서의 뮤신의 분비, 생성, 유전자 발현 조절과 연관된 in vitro 시험에서는 주 로 NCI-H292 세포가 사용되는데, 이때 유도제로 사용되 는 PMA는 $\mathrm{PKC}$ 의 내인성 활성화를 유도하여 유전자 전 사와 세포분화를 조절할 수 있는 자극인자로 알려져 있 으며 MUC5AC 유전자 발현을 유도하는 것으로 보고되 었다(Hewson et al., 2004). 이러한 기존의 보고에 근거하여 수행된 본 연구의 결과, 감태 추출물은 PMA로 증가된 MUC5AC의 유전자 발현을 농도의존적으로 억제하는 경 향을 보였다(Fig. 2).

종합하여 보면, 감태 추출물은 다량의 폴리페놀 성분을 함유하고 있어 호흡기 염증을 유도 및 악화시키는 활성 산소와 MUC5AC 유전자 발현을 억제함으로 호흡기질환 개선의 약물로의 개발 가능성을 제시하고 있으며, 뮤신 과다생성 억제에 관한 추가적인 기전연구가 필요할 것으 로 생각된다.

\section{ACKNOWLEDGEMENT}

This research was a part of the project titled 'Development and commercialization of functional ingredient for improving respiratory diseases using diarsenic seaweed', funded by the Ministry of Oceans and Fisheries, Korea.

\section{CONFLICT OF INTEREST}

The authors declare that they have no conflict of interest.

\section{REFERENCES}

Ahn MJ, Yoon KD, Min SY, Lee JS, Kim JH, Kim TG, Kim SH, Kim NG, Huh H, Kim J. Inhibition of HIV-1 reverse transcriptase and protease by phlorotannins from the brown alga Ecklonia cava. Biol Pharm Bull. 2004. 27: 544-547.

Athukorala Y, Jung WK, Vasanthan T, Jeon YJ. Anticoagulative polysaccharide froman enzymatic hydrolysate of Ecklonia cava, Carbohydr Polym. 2006. 66: 184-191.

Cragg GM, Newman DJ, Weiss RB. Coral reefs, forests, and thermal vents: the worldwide exploration of nature for novel antitumor agents. Semin Oncol. 1997. 24: 156-163.

Dhargalkar VK, Verlecar XN. Southern Ocean seaweeds: A re- source for exploration in food and drugs. Aquaculture. 2009. 287: 287-229.

Ellis EF. Asthma in childhood. J Allergy Clin Immunol.1985. 72: 526-539.

Folin O, Denis W. On phosphotungstic-phosphomolybdic compounds as color reagents. J Biol Chem. 1912. 12: 239-243.

Freeman BA, Crapo JD. Biology of disease: free radicals and tissue injury. Lab Invest. 1982. 47: 412-426.

Freeman BA, Topolosky MK, Crapo JD. Hyperoxia increases oxygen radical production in rat lung homogenates. Arch Biochem Biophys. 1982. 216: 477-484.

Heo SJ, Park EJ, Lee K, Jeon YJ. Antioxidant activities of enzymatic extracts from brown seaweeds. Biores Technol. 2005. 96: 1613-1623.

Heo SJ, Park PJ. Park EJ, Cho SK, Kin SK, Jeon YJ. Antioxidative effect of proteolytic hydrolysates from Ecklonia cava on radical scavenging using ESR and $\mathrm{H}_{2} \mathrm{O}_{2}$-induced DNA damage. Food Sci Biotechnol. 2005. 14: 614-620.

Hewson CA, Edbrooke MR, Johnston SL. PMA induces the MUC5AC respiratory mucin in human bronchial epithelial cells, via PKC, EGF/TGF-alpha, Ras/Raf, MEK, ERK and Sp1-dependent mechanisms. J Mol Biol. 2004. 344: 683-695.

Kang KA, Lee KH, Chae S, Koh YS, Yoo BS, Kim JH, Ham YM, Baik JS, Lee NH, Hyun JW. Triphlorethol-A from Ecklonia cava protects V79-4 lung fibroblast against hydrogen peroxide induced cell damage. Free Radic Res. 2005. 39: 83-892.

Kang KA, Lee KH, Park JW, Lee NH, Na HK, Surh YJ, You HJ, Chung MH, Hyun JW, Triphlorethol-A induces heme oxygenase-1 via activation of ERK and NF-E2 related factor 2 transcription factor. FEBS Lett. 2007. 581: 2000-2008.

Kim JH, Kang HM, Lee SH, Lee JY, Park LY. Antioxidant and $\alpha$ glucosidase inhibition activity of seaweed extracts. Korean J Food Preserv. 2015. 22: 290-296.

Kim KN, Lee KW, Song CB, Jeon YJ. Cytotoxic activity of green and brown seaweeds collected from Jeju Island against four tumor cell lines. J Food Sci Nutr. 2006. 11: 17-24.

Kong CS, Kim JA, Yoon NY, and Kin S. Induction of apoptosis by phloroglucinol derivative from Ecklonia cava in MCF-7 human breast cancer cells. Food Chem Toxicol. 2009. 47: 1653-1658.

Lee GW, Cho YH. Antioxidant Activity of Leaf Extract from Annona muricata. Review of Korea Contents Association. 2016. 14: 43-46.

Lee SI. The level of antioxidant enzymes in red blood cells of patients with chronic obstructive pulmonary disease. Tuberc 
Respir Dis. 1997. 44: 104-113.

Lillehoj EP, Kato K, Lu W, Kim KC. Cellular and Molecular Biology of Airway Mucins, Int Rev Cell Mol Biol. 2013. 139202.

Mutschler E, Derendorf H. Drug actions. CRC press, Inc., Boca Raton, Florida. 1995. 410.

Nieva Moreno MI, Isla MI, Sampietro AR, et al. Comparison of the free radical-scavenging activity of propolis from several regions of Argentina. J Ethnopharmacol. 2000. 71: 109-114.

Re R, Pellegrini N, Proteggente A, et al. Antioxidant activity applying an improved ABTS radical cation decolorization assay. Free Radic Biol Med. 1999. 26: 1231-1237.

Rogers DF, Barnes PJ. Treatment of airway mucus hypersecretion.
Ann Med. 2006. 38: 116-125.

Yoo CY, Kim SY, Park JW, Sung SA, Kim DA, Pakr JH, Xuan SH, Park SN. Antioxidant and Cellular Protective Activities of Ecklonia cava extracts against Reactive Oxyegen Species. J Soc Cosmet Sci Korea. 2015. 41: 287-294.

https://doi.org/10.15616/BSL.2021.27.4.334

Cite this article as: Lee SG, Kwon SO. Effects of Inhibiting Glycoprotein MUC5AC by Seaweed Ecklonia cava Extract in human Airway Epithelial Cells. Biomedical Science Letters. 2021. 27: 334-339. 